\title{
Re-theorizing the "Structure-Agency" Relationship: Figurational Theory, Organizational Change and the Gaelic Athletic Association
}

John Connolly

Dublin City University

Paddy Dolan

Technological University Dublin, paddy.dolan@tudublin.ie

Follow this and additional works at: https://arrow.tudublin.ie/clsart

Part of the History Commons, Organizational Behavior and Theory Commons, Sociology Commons, Sports Management Commons, and the Sports Studies Commons

\section{Recommended Citation}

Connolly, J. \& Dolan, P. (2012) Re-theorizing the 'structure-agency' relationship: Figurational theory, organizational change and the Gaelic Athletic Association, Organization,Vol 20, Issue 4, pp. 491 - 511. doi:10.1177/1350508412446101

This Article is brought to you for free and open access by the Centre for Consumption and Leisure Studies at ARROW@TU Dublin. It has been accepted for inclusion in Articles by an authorized administrator of ARROW@TU Dublin. For more information, please contact arrow.admin@tudublin.ie, aisling.coyne@tudublin.ie, gerard.connolly@tudublin.ie.

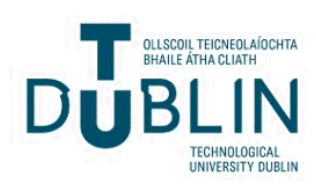


Authors: John Connolly and Paddy Dolan

Title: Re-theorizing the 'structure-agency' relationship: Figurational theory, organizational change and the Gaelic Athletic Association

Originally published in Organization 'online first'. Copyright Sage.

The publisher's version is available at:

http://org.sagepub.com/content/early/2012/05/07/1350508412446101.abstract

Please cite the publisher's version:

Connolly, John and Paddy Dolan (forthcoming) 'Re-theorizing the "structure-agency" relationship: Figurational theory, organizational change and the Gaelic Athletic Association', Organization.

DOI: $10.1177 / 1350508412446101$

This document is the authors' final manuscript version of the journal article, incorporating any revisions agreed during peer review. Some differences between this version and the publisher's version remain. You are advised to consult the publisher's version if you wish to cite from it.

Copyright (C) and Moral Rights for the papers on this site are retained by the individual authors and/or other copyright owners. 


\title{
Re-theorizing the 'structure-agency' relationship: Figurational theory, organizational change and the Gaelic Athletic Association
}

\author{
John Connolly \\ Dublin City University, Ireland
}

\section{Paddy Dolan}

Dublin Institute of Technology, Ireland

\begin{abstract}
This article illustrates how the figurational sociology associated with Norbert Elias provides an alternative theoretical framework for explaining the relationship between, 'individualorganization- society' and organizational change, and in so doing transverses what is conceived as a false dichotomy between structure and agency. Through an historical case study of the Gaelic Athletic Association in Ireland, the 'individualorganization-society' relationship is conceptualized as overlapping figurations and organizational change is explained as figurational dynamics-the shifting social interdependencies between the individuals and groups comprising an organization, between that organization and other organizations, between social groups on a higher level of integration and competition. In tandem with this, the article illustrates how changes in the sources of power and identity are connected with these figurational dynamics.
\end{abstract}

\section{Keywords}

figurations, identity, institutional theory, interdependencies, organizational change, power, structure-agency

Different theoretical explanations of change are underpinned by specific conceptualizations of the individual-organization-society relationship, or the different manifestations of this relationship, namely structure-agency or individual-society, within organization theory. Indeed, Reed (2005) postulates it is pivotal to the way in which theoretical explanations of organization are constructed and evaluated. Although the application of institutional theory is now one of the most dominant theoretical frames for explaining organizational change, as evidenced by the growing literature, questions on the interconnectedness of agency and structure persist amongst institutional theorists (e.g. Battilana, 2006, Leca and Naccache, 2006; Wright, 2009). For example, Wright (2009: 856) suggests that 'theories which permit both structure and agency' are necessary if institutional theorists are to overcome the seemingly paradoxical explanation of change implied within current conceptions of institutionalization. Consequently, Wright advocates Bourdieu's theoretical approach as 
a framework to enhance explanations of change based on institutional theory. One justification for this approach is to 'bring society back in', and as a consequence develop an explanation of institutional formation and change that bridge multiple levels. Indeed, in the course of describing what is meant by multiple levels-'individuals are nested within organizations which are nested within organizational fields which are nested within society' (p.859)-Wright implicitly brings an important question to the forefront: how do we theoretically explain the relationship between individualorganization-society? And how are theoretical accounts of this relationship deployed in explaining organizational change?

In this paper we demonstrate and argue for an alternative theoretical framework in conceiving of 'individual-organization-environment' relations, which contrasts with that provided by institutional theory. In that vein, our primary contribution to the literature is to demonstrate how the figurational-sociological approach associated with Norbert Elias provides a more comprehensive theoretical framework for explaining this relationship in the context of organizational change. We reconceptualize the meaning of both organization and individual, and in so doing, critically challenge the increasingly ubiquitous, if not dominant, theoretical frame of institutional theory in contemporary organizational theory.

While the utility of Elias's work to organization studies has previously been advanced (e.g. Newton; 2004; Dopson, 2001), our study differs significantly from several recent empirically-grounded papers (Dopson and Waddington, 1996; Dopson, $2001 ; 2005)$ that tend to focus primarily on Elias's concept of game models at the expense of the wider theoretical framework of figurational sociology. Thus, our paper involves an analysis of long-term figurational dynamics, the development of 'we' and 'they' identities and the intertwining of cultural and social processes. Following Elias, we argue that once organizations form, it is the shifting dependencies (and the changes in power and identity connected with this) between those individuals/groups at an intra-organizational level, between those at inter-organizational level, and between social groups on a higher level of integration and competition, and the overlapping and intertwining of these that explains the type and degree of organizational change. Our argument derives from a figurational analysis of an Irish sports organization, the Gaelic Athletic Association (GAA).

As with Holm's (1995) study of Norwegian fisheries, a study of the GAA in its own right may not be of interest to many, yet the GAA is an ideal case for examining the questions posed in this paper. First, there is the specific organizational structure of the GAA, with individuals comprising several different intra-organizational units, at different levels of integration, and other 'external' organizations simultaneously-a situation that pertains to the composition of many, if not all, organizations. And second, because of the type and extent of organizational change over a period of approximately 70 years (1884-1956), the GAA became increasingly centralized, and the functions provided by some organizational units became absorbed by other units at a higher level of orientation. However, such a process was punctuated by tendencies towards both 
decentralization and disintegration as struggles for greater autonomy for sub-units repeatedly emerged.

The paper is structured as follows. We begin by explaining some of the core theoretical constructs of figurational sociology. Second, we contrast institutional theory with the approach taken in this study. Following this, we outline the research approach and present our case study, providing a figurational explanation of organizational change. We conclude by highlighting how this paper advances the theorization of organizational change by applying figurational theory in conceptualizing the individualorganization-environment relationship and the implications that follow from this.

\section{Figurational Theory}

Figurational sociology, or process sociology as it is also known, has in recent times been applied, or advocated, as a theoretical framework within the domain of organization studies (Dopson and Waddington, 1996; Dopson, 2001; Newton, 2001; van Iterson, et al., 2001; van Iterson, et al., 2002; Dopson, 2005). However, Dunning and Sheard's (1976) seminal study can be identified as the first, after Elias, to address issues pertaining to modern organizational forms. Elias argued cogently and consistently against what he viewed as the contra positioning of the individual and his or her environment (or society); 'this optical illusion ... whereby these appear as two separate objects made of different substances' (Elias, 1984: 26). To overcome such dualisms Elias developed the concept of figuration-conceptualizing people in functional interdependence (mutual relationships). Figurations (webs of interdependent people) are characterized by fluid balances of power and are always in tension, shifting along a continuum between co-operation and conflict (Elias, 1978). From this perspective, all social entities are conceptualized as figurations-organizations, cities, political parties, nations, society (Elias and Dunning, 1966). Thus, we can see how figurations overlap and intertwine as people comprise multiple figurations. As such, figurational theory redefines what is currently conceptualized as a series of walls between society and organizations and individuals. Instead, we begin with figurations-individuals in webs of interdependence-at different levels of integration. It is important to emphasize, people are not 'in' figurations - such a phrase is antagonistic to the very conceptrather they comprise, form, figurations with others at different levels of integration, identification, cooperation and competition. Individuals always come in figurations and figurations are always formed by individuals (Elias and Dunning, 1966: 397). Equally, figurations are not ideal types imposed by the researcher on the people being studied; rather, they are as real as the people forming them (Elias, 1984: 14). Indeed, the central focus of Elias's work is human beings; people as 'whole people'-'not [just] their actions, their ideas, their experiences'-and ' $[t]$ their relations with each other' are the frame of reference for investigation (Elias, 1987: xxxii).

Consequently, we must seek to analyse change in terms of relationships rather than looking at individual actors or groups in isolation from one another; we can only 
understand actions, values or the attitudes of particular social actors in relation to others. In seeking to overcome modes of expression and thinking which categorized individuals and society (or social structure) as representing separate objects, Elias (1991) developed the concept of the 'We-I' identity balance as a tool for analysing how individuals are bonded to others (forming figurations at different levels of integration, identity and intensity) and the fluid nature of these balances. We-identification refers to feelings of a common bond between people, a sense of belonging (Elias, 1991). For Elias we-identifications are multi-layered and the intensity of identification varies at the different levels at which people are integrated-family, town, work organization, political organization, nation state. Elias's $(1991 ; 2000)$ work demonstrates how the emotional charge generated by we-identifications in conjunction with the specific structure of power relations can accelerate or impinge processes of integration and centralization for example. One of the reasons for this is that the we-feelings of individuals comprising a specific social group develop only in tandem with perceived differences with other 'they-groups'; we-groups and they-groups provide a function for one another. As such, the concept of figuration can refer to hostile or tense relations just as much as harmonious or mutually beneficial relations between people. Indeed, Elias's work directs particular attention at processes of conflict and resistance and between established and outsider groups for example (e.g. Elias and Scotson, 1994).

It is important to point out that Elias's conceptualization of 'interdependency' and 'power' differ significantly from how these concepts are understood and deployed within other theoretical frameworks. For Elias, implicit in this concept of interdependency is the relational aspect of function and power; wherever there is functional interdependence between people there are always balances of power. Elias (1978) stresses 'power balances', or 'ratios', as opposed to power as an amulet possessed by one person, or group, rather than another. Power and interdependence are processual and are a characteristic of all human relations. From this perspective no one is absolutely powerless and all social actors are constrained at some level, though this is not to deny that extremely unequal power relations do exist. What it does mean is that where social units are interdependent, where each provides a function for the other, each social actor is compelled to temper their actions to some degree.

Another of the key principles of Elias's perspective is that all social life is in motion or in process (Elias, 1978). This includes social structures, organizations, attitudes, values, norms, identities and even what might be loosely termed as mentalities (Elias preferred the term habitus, which referred to embodied social learning; the concept of subjectivity is similar). Therefore, to understand and explain any aspect of social life adequately, we must refrain from reducing social processes to states or substances; we must think processually rather than substantively.

\section{A figurational critique of institutional theory}


The concept of field, organizational field specifically, has become central to institutional theory (e.g. Reay and Hinings, 2005; Vaughan, 2008). Consequently, a comparison here with the concept of figuration serves as a useful starting point to elucidate the differences between the different approaches. Scott (1994 cited in Reay \& Hinings, 2005: 353) defines an organizational field as 'a community of organizations that partakes of a common meaning system and whose participants interact more frequently and fatefully with one another than with actors outside the field'. Explicit then within the theoretical construct of field is that relations between different actors are conceived as 'interactions' rather than fluid interdependencies. For instance, Vaughan (2008), in her study of NASA's flawed decision to launch a space shuttle, states: 'Neither field was a network because not all interacted with each other or NASA' (p.72). This concept of 'interaction' implies only relationships where direct contact, albeit at different levels or intensities, between individual actors occurs. Yet, as Mennell (1989: 95) points out from a figurational perspective, 'people are also interdependent with people with whom they never interact, never meet, and are affected by the activities of people far down a line of interdependence'. Furthermore, the deployment of 'interactions' and/or interdependencies within institutional theory, as illustrated above, presupposes that individuals are independent prior to some encounter rather than in continuous and fluid interdependence with others through which their actions, behaviours, and thoughts are shaped.

More recently Fligstein and McAdam (2011) introduced the concept of 'strategic action fields' to capture the interaction between actors in the pursuance of their various plans. Like other models following Bourdieu the problem of field delineation remains. Fligstein and McAdam criticise Bourdieu for focussing on the individual actor and neglecting the actions of collective entities. Here the conflation of individual and collective tends to risk the assumption of common purposes and harmonious action within the collective. There is of course much conflict in organizations over who gets to speak and act on behalf of the collective. In the strategic action field actors 'interact with knowledge of one another under a set of common understandings about the purposes of the field' (Fligstein and McAdam, 2011: 4). But interdependencies, and indeed interactions, often occur in the absence of uniform views on what a figuration is for.

Despite the pre-eminence of institutional theory as a frame for explaining organizational change, a growing number of institutional theorists have identified the structure-agency relationship, implicit within institutional theory, as problematic (e.g. Battilana, 2006; Wright, 2009). Attempts to transcend this have primarily involved the knitting or grounding of wider social theoretical perspectives with institutional theory structuration theory (Barley \& Tolbert, 1997; Scott, 2008); critical realism (Leca and Naccache, 2006) and Bourdieusian theory (Battilana, 2006; Wright, 2009). Yet, despite this, we contend, that these approaches fail to adequately theorize the empirical phenomena to which they relate. Both structuration theory and critical realist approaches impose duality-in some critical realist approaches the duality of structure-agency is actually advocated (e.g. Leca and Naccache, 2006; Reed, 2007; Hodgson, 2007). In the case of structuration theory Giddens relies on a very 
rationalistic, voluntaristic model of the individual, stressing interaction between individuals rather than interdependencies across long chains of people spread across space and time (Kilminster, 1998: 133-5).

The wedding of Bourdieu's work to institutional theory has also been advocated as a means to cross this difficult terrain (Battilana, 2006; Wright, 2009). Like Elias, Bourdieu's approach is relational, incorporates the concepts of habitus and power, and rejects the structure-agency dichotomy (see Paulle et al, 2011; Author, 2009). Bourdieu's (1990) concept of field-a version of which has been subsumed by institutional approaches to organizational studies-has been specifically identified and advocated as a means to overcome the structure-agency dilemma within institutional theory (e.g. Wright, 2009; Battilana, 2006). However, we argue that even here institutional theorists continue to sustain the dualism of structure-agency. For instance, in Battilana's (2006) efforts to explain how individuals' social position may enable action despite institutional pressures, the distinction between individual and environment is actually preserved - individual action is conditioned by organizations and institutions, while reciprocally individual actions shape organizations and institutions (p.655). We argue that the figurational approach effectively bypasses debates between structure and agency, and between macro and micro levels of organization, as all are different sides of the same coin.

Wright's (2009) study which is based on the sport of English cricket has certain symmetries with our approach-an historical and relational analysis and the integration of social class tensions. Indeed, Wright's analysis of the power struggle, conceptualized as a contest for capital, between individuals within and between cricket clubs, and between units at different levels including class relations at the level of society resonates closely with our study. However, we emphasize how individuals constitute several different social organizations simultaneously and how the strength of their identification towards one unit over another, and the emotional charge associated with this, generates tensions and ambivalences. Moreover, this raises questions as to how we theoretically conceive of such social units and, in this instance, the capacity for the concept of fields to adequately capture this. Our paper illustrates how the combination of theoretical concepts, of figuration and we-identity, can address this. Indeed, while institutional theorists increasingly recognize the importance of identity in institutional change or resistance (Misangyi et al, 2008; Creed et al, 2010), there remain limitations within their approach here too. There is a failure to adequately account for multiple we-identifications and how this impedes or facilitates change. For instance, Misangyi et al (2008) illustrate how the fostering and advancing of an anti-corruption identity was critical to generating an anti-corruption institutional logic in competition to the countervailing logic. Emphasis is given to a single emergent anti-corruption identity which tends to mask any tensions or ambivalence generated by the fact that individuals have multiple we-identifications. In this paper we demonstrate how people hold multiple we-identifications simultaneously, the different, oscillating strengths of these identifications and of the emotional charges connected with them, the tensions 
and ambivalences these generate within and between individuals and social unit(s) they comprise, and how this is interconnected to organizational change.

This is not to suggest that institutional theory bypasses contradictions and mutability internal to specific institutional logics (see Rao et al, 2003). Here too it is clear tensions between logics also foster change, but problems remain in the definition and delineation of each logic. They appear more like Weber's ideal types than real cultural formations based on social interaction, interdependencies, cooperation and antagonism. The logic is constructed by the analyst from activities of people, and subsequently used to explain those very activities. A figurational approach locates competing cultures more tightly to inter- and intra-group dynamics, though culture retains a relative autonomy.

We also take issue with the contention that institutional theory can 'bring society back in' (Friedland and Alford cited in Goodrick and Reay, 2011; see also Wright, 2009), for it appears to be based upon a very limited conception of society. Within Goodrick and Reay's work the social is seen as comprising rules, norms, symbols and practices which penetrate the individual organization. To distinguish between corporate culture and 'wider society' the latter is designated as an institutional logic. It is really conceived as a normative order, and therefore varies little from cultural structuralist theories of social action. The institutional order is treated as a social fact, objective and detached from the activities of people, in much the same way that Durkheim depicts society or Weber constructs ideal types (as Goodrick and Reay do). As Elias (in Elias and Dunning, 2008: 153) argues, Durkheim tends 'to regard norms and rules almost as if they had an existence independently of persons' (see also Elias, 1978: 119-20). In the case of Goodrick and Reay, ideal types are constructed in part from data pertaining to the activities of an occupational group and partly it seems from the common-sense understanding of how markets, states, professions and corporations operate in principle. Once these ideal models are developed as concepts, the 'reality' of organizational life is compared against these different types of institutional logic to see the relative weight of influence that each logic brings to bear. The relative weights change over time, but there is no explanation for the mechanisms of change, nor is there a clear understanding of how pure the boundaries are between different institutional logics. Rather than inventing 'ideal types', Elias argues for the elucidation of real types of social organization (Elias, 2000: 533n; Elias and Dunning, 1966: 396).

In conclusion then, while there are certain symmetries between figurational sociology and institutional theory, there remain critical contrasts between these approaches and consequently in how they explain organizational change.

\section{Research method and sources}

The GAA was founded in 1884 and is one of the largest sporting and cultural organizations in Ireland with over 2,600 affiliated clubs and an estimated membership 
of 700,000. It also has a growing international presence with 350 affiliated clubs based across the globe. We have restricted our empirical analysis in this paper to the period 1884-1956 for the purpose of giving greater weight to theoretical analysis and discussion. By 1956, the organizational structure of the GAA comprised the following:

- Clubs, the basic unit of the GAA (2684 units in 1956);

- County committees (32 in Ireland) comprised of representatives of clubs in each county;

- Provincial councils (4 units) comprised of two representatives from each county in a province; ${ }^{1}$

- Central council (1 unit) comprised primarily of one representative of each county committee, representatives of units outside Ireland, the chairs of provincial councils and representatives of other units such as the central college council. The general-secretary of the GAA (a paid employee) is a member, but with no voting rights (the unit has over 40 members in total);

- Annual congress (1 unit) made up of delegates from each county.

Congress, which meets annually, comprises over 300 delegates, the majority of which are representing county committees and clubs (the clubs in a county elect their delegates). In addition, both the central council and past presidents are also members. It is vested with the authority for determining policy and the powers to accept or reject changes to the rules governing the organization, including its organizational structure. Between congresses ongoing operational responsibilities are vested in the central council, the Supreme Governing Body of the Association between congresses (GAA, 1956: 71); the composition of this unit has been a source of persistent conflict. In addition, from 1946 a smaller group known, initially, as the executive committee (with 12 members) (GAA, 1946a), subject to the jurisdiction of the central council, was authorised to manage 'routine matters'. This unit comprised the president, presidents and secretaries of the four provincial councils and the secretary general (GAA, 1956).

Those who comprise units at a higher level of integration such as the central council and the executive committee are also members of county committees and clubs and, in some cases, provincial councils. Clearly, these same individuals also comprise other social organizations apart from the GAA. This overlapping membership allows us to examine, from a theoretical-empirical perspective, the permeability of organizational (intra and inter) boundaries, specifically the individual-organization-society relationship.

Our data set consists of several categories of materials and sources: published historical narratives of the organization and its subunits (O'Sullivan, 1916; Gallogly, 1984; McTernan, 1984; Mandle, 1987; De Búrca, 1999; Garnham, 2004a; Hunt, 2008) and of several social units interdependent with the GAA (Garnham, 2004b; McGee, 2005; Hunt, 2008); official minute books and annual reports of the GAA's annual congress from 1887 to 1956 , which document the various motions for change and the discursive interactions and strategies mobilised for or against change; official minutes 
pertaining to approximately 2,500 meetings of central and regional administrative and governing subunits-central council, provincial councils, clubs, county committeesacross Ireland, covering a variety of historical periods; we also had access to reports of specialist committees, annual reports and constitutions of the GAA since its foundation. These sources were supplemented by; reports within national and regional newspapers, autobiographies and biographies of officials (e.g. Blake, 1900; Ó Riain, 1994); journals edited or officially controlled by the GAA (e.g. Gaelic Annual) and by individual GAA members (e.g. The Celtic Times from 1887-1889); as well as academic socio-historical data on the GAA (e.g. McMullan, 1995) and social, political and economic histories of Ireland (Lee, 1989; Kee, 2000; McGee, 2005) . Combining this data allowed us to document over a considerable time period when changes to the organizational structure occurred; the functions of units/organizations; shifts in function, power and identity and interconnected with this the resources and discourses mobilised by various individuals and groups. Data analysis followed the approach advocated by Elias-theory generation and data identification as close parallel research activities rather than some deductive scheme. Therefore, the theoretical elaboration will be addressed as part of the analysis and synthesis of the case study.

Following Elias, we have sought to steer a course between the extreme reflexivity of phenomenological approaches and the positivistic assumptions of scientistic objectivity. Like the people we studied in the GAA, we too comprise figurations, dependent on the theories, concepts and knowledge already advanced by other researchers. As such, our synthesis of data has involved constant 'two-way traffic' (Elias, 1987: 20) between facts and explanations. Elias (1987) maintained that the research process included a combination of involvement and detachment with the objective of developing 'a steadily expanding body of theories or models and an equally expanding body of observations about specific events by means of a continuous, critical confrontation leading to greater and greater congruity with each other' (p. 20). While Elias advocated relative detachment, this is intended to produce a more reality-congruent picture of society in order that subsequent interventions have a greater chance of meeting with some success. Similarly, we seek more reality-congruent knowledge of organizations so that the myths surrounding their success or otherwise can ultimately be dislodged (see Elias, 1978: 50-70). This constitutes one aspect of the critical potential of the figurational approach to organization studies.

\section{Case study: the organizational transformation of the Gaelic Athletic Association}

\section{Organizational formation as figurational dynamics}

We begin by explaining the figurational dynamics through which the GAA came to be formed. In so doing, we challenge existing organizational theory based on the 
premise of individuals and society as separate interacting entities. The GAA was established by a group of individuals drawn primarily from the Irish middle/lower middle-classes - shop assistants, clerks, journalists and farmers (Mandle, 1987). Part of a rising social group in Ireland seeking greater control of, and access to, the functions of power in Ireland, they were resisted by a declining, but established, Anglo-Irish ascendency seeking to maintain their privileges. The power balance between these social groups had shifted following a series of land acts which gave greater 'economic' security, and social power to middle and lower middle class farmers in Ireland. Similarly, in urban areas, the expansion of trade networks with Britain facilitated the growth and increasing social power of the Irish commercial middle-class (Author, 2005). Yet, despite their rising situation a sense of inferiority persisted amongst those comprising the Irish middle classes, stemming from their failure to fully achieve the status and position they desired in Irish society. It was this structure of tensions that at one level led them to seek and develop differences with the established group and, on another, to accommodate some of the values and ethos of the established. ${ }^{2}$ As such, their conflicting feelings and emotions were channelled into different social practices, embodied in the revival of 'native' Irish cultural activities, such as the promotion of the Irish language (see McDevitt, 1997) and in the formation of literary and political debating clubs (McGee, 2005). In the sporting sphere, Irish athletes agitated for Irish games to be revived and for athletics to be brought under 'Irish' control. Two of these athletes, Michael Cusack and Maurice Davin, following several previous attempts to form such an organization, were part of a group which established the GAA in 1884 (Ó Riain, 1994). Both men were members of rising Irish social classes, and to that extent formed part of the wider figuration comprising rising social groups and established and declining social groups.

Thus, we see here how the changing structure of interdependencies between social groups in Ireland and Britain intensified the competition between a rising 'Irish' middle class and a declining 'Anglo-Irish' upper class, and how the emotions and feelings this aroused crystallized into different practices (Author, 2009) such as the playing of native Irish games and in the formation of 'Irish nationalist' organizations such as The Young Ireland Society (YIS) (McGee, 2005), the Society for the Preservation of the Irish language, and the GAA (see Ó Riain, 1994).

In this sense, organizations are formed by people already shaped by ongoing and changing interdependencies, so that there isn't a moment of first interaction between a formed organization and its environment. This is reinforced by an analysis of the developments that followed the formation of the GAA. When the GAA was established in 1884 many sporting clubs already functioned throughout Ireland and several national sporting associations were in existence (Ó Riain, 1994; Hunt, 2008). Two versions of football, soccer and rugby, were governed by national associations-the Irish Football Association established in 1880 and the Irish Rugby Football Union formed in 1874 (Garnham, 2004a), while athletic clubs competed under the rules of the English Amateur Athletic Association (AAA) (Ó Riain, 1994: 22-27). At that time athletic clubs generally comprised members of the Irish middle classes and the Anglo-Irish and 
English upper-middle classes (see Ó Riain, 1994). Consequently, the establishment of the GAA, with the stated aim of taking over the function of governing athletics, both embodied and symbolized a felt threat to those then governing athletics and the wider dominant social group from which they were drawn. As competitive tensions escalated, several of the founding members of the GAA sought to garner support for the nascent organization from existing athletic and football clubs (Ó Riain, 1994: 76). In response, those opposed to the GAA began to organize themselves, and an athletics organization, the Irish Amateur Athletic Association (IAAA), was formed, also claiming to be the representative body for athletics in Ireland (De Búrca, 1999: 19). In the struggle for greater control over Irish sports, representatives of the GAA drew on cultural narratives of 'ancient Ireland' and emphasized the GAA's nationalist and Gaelic-Irish credentials, as opposed to Anglo-Irish (Author, 2009), while simultaneously labelling not only the IAAA as English and anti-nationalist, but also the clubs who competed in sports under English rules (e.g., see Celtic Times, 1887, 5 March, p. 5). This illustrates again the concept of interdependence, and how it relates to competitive as well as cooperative bonds; the development and employment of a particular discourse by specific groups seeking to establish legitimacy and/or dominance are 'explainable only in the context of the specific figuration formed by individuals and the specific interdependences binding them together' (Elias, 1984: 66). The structure of tensions within the figuration comprised by the social groups in Ireland crystallized into different felt emotions and anxieties and for the rising Irish served to foster a particular national we-image representing their ideals and wishes. Moreover, this increasingly 'national' ideal, and the symbols which represented it, became instrumental in integrating members into the GAA.

It is important to emphasize that the 'collective' social habitus of those rising groups was interpenetrated, for the various individuals at different gradations and in different ways, by tensions generated by a whole series of overlapping and intertwined figurations of class, religion, ethnicity, regions and sporting organizations in Ireland. It was this complex and fluid web of interdependencies that shaped the GAA as a distinct organization, becoming more integrated and coordinated. This aspect is critical, for it dispels the idea that once organizations are formed some kind of invisible impermeable boundary is established between organizations and 'their' environment(s).

\section{Overlapping figurations and organizational transformation}

As several members of the nascent GAA sought to consolidate and expand the GAA they formed a central council of executive and administrative officers as the first organizational committee of the GAA and it was agreed that each sports club affiliating would have two members on this central council. Individuals and clubs partaking in, or seeking to engage in, the sports of athletics, Gaelic football, ${ }^{3}$ hurling ${ }^{4}$ and handball could affiliate to the GAA (GAA, 1885: 13). In the first couple of years over 400 clubs affiliated (Mandle, 1987: 31), increasing the pressure for greater coordination and cooperation at 
an intra-organizational level. Consequently, in 1886 various organizational functions were devolved to regional units known as county committees (O'Sullivan, 1916: 38), ${ }^{5}$ made up of elected representatives from the affiliated clubs within each county in Ireland. At the same time, the structure of the central council was changed so that it would no longer contain two members from each affiliated club; such a structure would be unworkable due to the number of clubs now involved. Instead, four elected members from the national congress-held once a year, and made up of two delegates from each club-would now form part of the central council. The organizational structure of the GAA now comprised four categories of social unit-a central council, a national congress, and county committees and clubs. Here we encounter, again, the inadequacy of a theoretical lens taking the 'separate' individual as the frame of reference. For instance, some individuals were members of central council, a county committee and a club simultaneously-at no point did they comprise one unit and not the others.

In these early years the power balance within the GAA figuration lay in favour of clubs, a differential that existed owing to the structure of functional interdependence. Many clubs had an ephemeral existence; sporting contests were often organized on an intraclub basis with competition rules varying from region to region; and, interconnected with this, the standardization of game-forms remained limited. Consequently, many clubs had a low level of dependency on the function of central council as a national rulemaking and coordinating body; they played by locally agreed rules in ad-hoc arrangements and, as a result, tended to remain ambivalent towards affiliation to any national sporting organization-even clubs which competed or organized tournaments under GAA rules failed to affiliate to the GAA (see Mulvey, 2002b: 1-10). Furthermore, the central council was financially dependent on the clubs as their primary source of income was affiliation fees from clubs and gate-receipts from centrally sanctioned interclub fixtures. For example, in 1888 affiliation fees accounted for one third of all income despite the fact that many clubs did not pay their fees (O'Sullivan, 1916: 74). As the number of sports tournaments increased and formal competitions were established under GAA rules, there was a gradual shift in the power ratio as the clubs' functional dependence on the central council, as a rule-making, standardizing and organizing body, advanced. More and more clubs were bound to the central unit; inter-club competitions ensured coordinating functions were necessary and, interrelated with this, the frequency of violent and acrimonious disputes, both on and off the field of competition, added to the need for third-party regulating and adjudicating functions. As a result, the central council and, to an extent, county committees, provided not only an organizational structure for inter-club activities, but also functioned as third-party regulators. Just as significantly, the central council provided both an integrating and emotional function for club members. As central council comprised many of the GAA's founding members, it was to an extent perceived by many of those comprising clubs as the embodiment of the GAA, and so functioned as a medium through which club members could display their allegiance to nationalist ideals through affiliation. Emotional belonging and affiliation were intertwined and were critical to the social and 
financial power of the GAA's central council and the extent to which the organization expanded in comparison to other sports organizations.

This too illustrates how the power balance pertaining within the GAA figuration was functionally connected with the power balance at an inter-organizational level. Many of those comprising the wider GAA figuration and, in particular, its leading representatives sought and required the affiliation of clubs in the struggle with the IAAA; the social power of the GAA, and the IAAA, was based on their ability to function as the primary organization for the coordination of athletic clubs and competitions in Ireland.

The problem posed by concepts such as individual-organization-society reemerges here. In looking at the functional relationship between clubs, county committees and central council, while referring to different social entities, it is clear several individuals were members of (comprised) each of these units simultaneously. Indeed, not only were they members of each of these GAA units, they were also members of other social organizations (see, e.g. table 1).

\begin{tabular}{|c|c|c|c|c|}
\hline $\begin{array}{l}\text { Social } \\
\text { organization } \\
\text { Individual }\end{array}$ & $\begin{array}{l}\text { GAA Club } \\
\text { member }\end{array}$ & $\begin{array}{l}\text { GAA County } \\
\text { Committee } \\
\text { Member }\end{array}$ & $\begin{array}{l}\text { GAA Central } \\
\text { Council Member }\end{array}$ & Other Organizational Affiliation \\
\hline Thomas Dooley & St Finbarr's & Cork & yes & Irish Republican Brotherhood (IRB) \\
\hline Thomas Slattery & Tralee Mitchels & Kerry & yes & IRB \\
\hline Patrick Tobin & Brian Boru & Dublin & yes & IRB \\
\hline Richard Blake & $\begin{array}{l}\text { Navan Cycling and } \\
\text { Athletic Club }\end{array}$ & Meath & yes & $\begin{array}{l}\text { Freemans Journal (newspaper } \\
\text { organization) }\end{array}$ \\
\hline Michael Deering & St Mary's & Cork & yes & IRB; YIS \\
\hline Fr. O Connor & St Finbarr's & Cork & no & Catholic Church \\
\hline Tom Fallon & $\begin{array}{l}\text { Killenumary } \mathrm{P} \quad \mathrm{A} \\
\text { McHughs }\end{array}$ & Leitrim & no & National league \\
\hline $\begin{array}{l}\text { Patrick A. } \\
\text { McHugh }\end{array}$ & Sligo (town) & Sligo (county) & no & $\begin{array}{l}\text { Member of Parliament (Anti-Parnellite } \\
\text { Nationalist). }\end{array}$ \\
\hline James Nowlan & $\begin{array}{l}\text { Confederation } \\
\text { Hurling Club }\end{array}$ & Kilkenny & yes & $\begin{array}{l}\text { IRB; Gaelic League; Member of local } \\
\text { council (Labour-nationalist politician). }\end{array}$ \\
\hline
\end{tabular}

Those who constitute an organization simultaneously constitute, along with many other people, different social organizations and wider society-a series of different overlapping figurations-and as a result tend to be subject to conflicting pressures (Dunning and Sheard, 1976). Consequently, in the case of the GAA individuals who comprised clubs, county committees, national congress and the central council, also constituted other social organizations such as the Catholic Church, political groups (both constitutional and revolutionary), towns and even other sporting organizations. For instance, by 1886 the four vice presidents, the treasurer and the three secretaries of the GAA, all of whom were on the central council, were also members of a secret society, the Irish Republican Brotherhood (IRB), which sought an independent Irish republic (Mandle, 1987: 31). This situation was replicated in other GAA subunits also. These overlapping memberships allied with the allegiances and we-feelings strongly felt towards some social organizations more than others exasperated tensions that led to 
open conflict between members of the GAA. For example, in the late 1880s hostilities emerged particularly between those who were also members of the IRB and those opposed to all secret societies (the clergy and constitutional nationalists) (Mandle, 1987; McGee, 2005). The IRB faction, who comprised the majority of central council, were intent on enhancing the decision-making functions of the central council as they felt it would allow them greater control to direct the organization in the interests of the IRB (see McGee, 2005: 165), particularly the organization's subunits-the county committees and clubs (Mandle, 1987: 38). This attempt at further centralizing power within the organization was opposed by many comprising clubs and county committees, particularly those units influenced and controlled by members of the clergy (see, e.g Mandle, 1987). This overlapping, multi-tiered figuration-club, county committee, and central council and of other organizations/social units-emphasizes the permeability of the boundaries between groups and organizations, the multi-polar structural power relations and the complex, multi-layered nature of identity. For instance, the tension and conflict between those individuals comprising the IRB, the Catholic Church and the GAA simultaneously, cannot be conceived as part of an 'external' environment-as 'outside' social forces. The current means of conceptual orientation within institutional theory (e.g. Battilana, 2006; Wright, 2009) are not adequate for explaining this, even where attempts have been made to transcend this issue. One of the problems with the conceptual repertoire deployed is the modes of thinking and observation they sustain; it creates the impression that we must seek to explain how these separate independent entities interact with each other (e.g. Fligstein and McAdam, 2011). Such models

encourage the impression that society is made up of structures external to oneself, the individual, and that the individual is at one and the same time surrounded by society yet cut off from it by some invisible barrier (Elias, 1978: 15).

We see this for example when Wright (2009) speaks of 'individuals nested in organizations', or when Battilana (2006) refers to individuals embedded in the environment, yet the empirical evidence provided here is not only significant in questioning the prevailing view that organizations (or intra-organizational units comprising them) interact with an external environment, it also challenges the dominant understanding of the very concepts of organization and individual. If we begin to conceive of individuals with open valences bonded to a whole range of different and overlapping figurations, we gain a different image of individual-organization-society with significant ramifications for how we conceive of organizational boundaries.

\section{The disintegration of the GAA: Shifting power balances and we- identifications}

Although divisions existed within the central council, it was predominantly comprised of members with IRB affiliation, and they now sought to exert greater organizational control over clubs and county committees by expanding the functions of the central 
council at the expense of county committees and clubs. Membership of the GAA by IRB activists was to an extent based on instrumental needs-control of the GAA would enhance the strength and position of the IRB-and emotional needs-identification with 'Gaelic culture' embodied through the GAA. While these men identified strongly with the nation-building objectives of the IRB, others comprising central council, clubs and county committees identified more closely with their respective local unit(s) and resented or feared a decline in the power chances of these units. Some feared a personal loss of influence and social meaning they obtained from their function within these social units. For instance, members of the clergy were influential within many clubs and wished to retain or extend their power and influence which they felt was under threat (see Mandle, 1987: 28).

Yet, there were some clubs, mainly those influenced by IRB members, which supported the aim of enhancing the decision-making powers of the central unit. That such a process involving the further centralization of functions was resisted, and to all intents and purposes reversed, can be explained by the prevailing structure of interdependencies. Representatives of clubs in a particular county constituted the county committee; this unit held administrative and organizational functions pertaining to inter-club activities within a county boundary (GAA, 1885). As such, it provided the opportunity for the representatives of clubs to influence decisions which could serve their interests with the result that the elected leadership of many clubs favoured the devolution of further functions to county committees rather than any loss of functions. Second, the wider social structure in which clubs functioned facilitated the decentralization of functions. The GAA's membership (players and administrators) came mainly from the lower middle classes (see Hunt, 2009), but also some of the rural and urban labouring classes (McMullan, 1995) and many struggled financially. Consequently, the social organization of GAA events generated a pressure for clubs to provide financial resources for the provision of refreshments, medals and prizes at tournaments to participants and in particular for players travelling expenses. In these circumstances many clubs and county committees were unwilling or simply unable to submit affiliation fees to the central council (see Nolan, 2005: 8) and resented the process (see O'Sullivan, 1916: 82). Yet the central council depended on clubs for funding through affiliation fees.

Another factor that facilitated the prevailing interdependency structure was the slowness of the expansion in inter-regional sporting competition, and consequently the requirement for greater central co-ordination at a national level. Although a shift away from predominantly ad-hoc localised competitions was taking place, this process was at an early stage as evidenced by the level of club involvement in national competitions (see Mandle, 1987: 76), and by the lack of standardization of game-forms at national level in the late 1880s and 1890s.

Overall, then, the interdependency pattern between central and regional units was asymmetrical as the balance of social power still lay with the clubs and county committees. The extent of this is evident from the fact that in 1888 a new constitution was drafted not only securing the existing functions of clubs and county committees, but 
enhancing them, particularly the functions of county committees (controlled by clubs) (Ó Riain, 1994). However, to focus on the functional asymmetry between intraorganizational units does not adequately explain this complex process and the subsequent disintegration tendencies. Decentralizing and disintegrating tensions were intertwined with, and overlapped by, other figurational dynamics at different levels of integration.

By the 1890s tensions between the different political groups in Ireland had escalated (Mandle, 1987; McGee, 2005), and the GAA split along parallel lines, again illustrating the interwoven nature of figurations. Internecine disputes arising from this social tension, at both club and county committee level, resulted in many clubs and county committees disbanding or disaffiliating from the GAA (Mandle, 1987), all of which further decreased the functional dependence of the subunits on the central council. The power balance was in proportion to their functions for each other (Elias, 1978: 74). Where the central council's functional value for its sub-units declined, so did its power and control over the sub-units. For instance, although central council was financially dependent on clubs, the rules were amended in 1896 to allow clubs retain two thirds of the affiliation fees collected (O'Sullivan, 1916: 122).

On the other hand, many of the different units remained bonded through various cooperative interdependencies; the remaining affiliated clubs and county committees remained connected through the organization and completion of inter-unit sports fixtures and, to an extent, the requirement for adjudicating functions. For instance, in 1891 , although the number of affiliated clubs had declined to 220 , the secretary general of the GAA was moved to admonish clubs for the number of appeals arising from sporting contests being sent to the central council for adjudication (Sport, 1891, 7 February, p. 7). Emotional valences also existed, for the GAA comprised a significant number of men who were members of the IRB. They were bonded to one another through organizational interdependencies and by their identification with the IRB and, interrelated with this, the emotional bond to a specific abstract ideal the IRB represented-an independent Irish republic (see McGee, 2005). Taken together these interdependencies sustained a figuration that still required coordinating functions at different levels of integration.

To demonstrate further how figurations at different planes are interwoven we illustrate how 'regional' tensions also permeated the GAA figuration-the different regional we-identities and the intensity with which they were felt by those comprising these units. For instance, at that time the then general secretary of the GAA, Maurice Moynihan (a member of the central council of the GAA), was also a leading member of the IRB (secretary for IRB in county Kerry), a member of the John Mitchel GAA Club (in county Kerry) and secretary of Kerry GAA county committee (his native county) (CLG, 1984; $7^{7}$ McGee, 2005). Betraying the emotional valences that bound individuals to social units based on regional identity, he goaded some of his colleagues on the central council of the GAA by sullying the organizational capabilities of the regional GAA unit they were affiliated to in an acerbically written letter in a national newspaper: 
...if Dublin [county] is the natural headquarters and the Dublin Gaels the pioneers of the association, how is it they could not hold their county convention in time ...We who live at the back of God speed down here in Kerry [county] managed to have all our arrangements made (Sport, 1891, 7 February, p. 7).

What is evident from this is the meaning attached to 'his' county (weidentification) as opposed to the county (they-identity) of his opponents. A further example of the intensity of the emotional charge generated by county weidentifications can be seen from a dispute which arose in 1895 out of a sporting contest between the county representative teams of Cork and Dublin. At a subsequent central council meeting in which the contest was discussed, Michael Deering (county Cork representative) and Patrick Tobin (county Dublin representative) had to be prevented from coming to blows. That both men were also members of the IRB (See Mandle, 1987: 105; see also table 1) is again indicative of the many layers of we-identification pertaining and the different yet interlocking planes they refer to.

At different levels, for those comprising clubs and county committees, and even central council, they were both partners and opponents (see O'Sullivan, 1916: 129, 133, 140). Significantly, it was these interdependencies, of both a cooperative and conflictual nature, that actually sustained the requirement for coordinating and adjudicating functions at higher levels of orientation. So, while some representatives of county committees (and clubs) sought greater autonomy for their units, their dependence on each other and on some form of coordinating and rule-making body remained. This interdependency structure, and the balance of tensions within it, provided the context in which the creation of a further tier of co-ordination emerged between 1899 and 1903-new intra-organizational units to which many of the functions at central council level were decentralized. These new regional bodies, known as provincial councils, comprised representatives of county committees (GAA, 1907)-illustrating the increased functional powers of county committees.

\section{The interweaving of figurations at higher levels of integration}

By 1902 clubs and county committees began to re-establish and affiliate to the GAA as the IRB, which was also re-united after a split, again sought to influence and direct the organization by placing their members in clubs and county committees (Mandle 1987:118-123). The growth in affiliated clubs and county committees involved both an expanded and more diverse membership requiring more differentiated competitions, more integrated coordinating functions and a central authority to synchronize these various tiers of activities (see Mandle, 1987: 133; Nolan, 2005: 75-86). As more clubs and county committees were integrated, their social existence became increasingly interdependent through the division of functions. In the case of county committees, 
their social existence was strengthened by the increase in the number of clubs affiliating within the county boundary and then by the related administrative and coordinating functions created by this-the functional interdependencies between clubs, and between clubs and county committees. As in Elias's (2000: 287) account of the various aristocratic houses and regions in France:

The separate identity of each region, the special interests and character of each territory, were still strongly felt. However, their union under one and the same house and partly under the same administration, did remove a series of obstacles in the way of fuller integration.

Critical in explaining this tendency towards greater integration, and with the strengthening of the function of central council, is the escalating and amplifying ideal of the nation, which itself is inseparable from changing power relations in Ireland and between Ireland and Britain. As nationalist sentiment rose significantly in Ireland in the early twentieth century, tensions increased between groups seeking greater autonomy or full independence for Ireland and those seeking to sustain British governance and sovereignty in Ireland (see Lee, 1989). Sports and sporting organizations became increasingly positioned as Irish or British-the playing of cricket and Britishness were equated, and cricketers were tainted as anti-Irish (Hunt, 2008: 194). At the GAA's annual congress of 1901, a delegate declared: 'that we call on the young men of Ireland not to identify themselves with Rugby or association football or any other form of imported sport' (GAA, 1901). This was indicative of wider desire amongst many members of the GAA's leadership, and general membership, to hold a monopoly of control in Irish sport, and to what extent the boundary would extend in relation to other sports. These feelings were soon manifest in the GAA's constitution as motions to ban members of British policing and military personnel in Ireland playing 'Gaelic' sports, and on GAA members playing 'foreign' sports, were passed at the GAA's annual congress (De Búrca, 1999: 71).

The claim to be the one 'true' organization for Gaels and nationalists was also a compelling process in uniting the GAA's component units and paved the way towards greater national unification of the organization, and indeed, in extending its membership; the GAA became a means for people not just to symbolically identify with Gaelic nationalism, but to embody it.

The conflation of nationalist Ireland with the GAA helped expand the membership and in turn increase the interdependencies between all the units-more clubs and more differentiated inter-club competitions based on age and ability and the organizational and administrative tasks generated by this. As such, these processes acted in combination and facilitated a widening of the circles of identification between GAA members across Ireland-a strengthening and widening of the GAA national weidentity. Despite advances in mutual identification among the different social units constituting the organization other, even contradictory, we-images and we-feelings, such as club and county, simultaneously existed. The interdependencies which brought 
the units together or separated them-animosities generated by previous sporting encounters, and which often provided the seed for further hostilities-were equally important in cementing the different layers of we- and they-identities and maintaining their durability.

\section{The expansion in interdependencies and shifting power ratios}

In the mid 1920s the integration of more and more clubs, over 1200 by 1925 (GAA, 1925), increased both competitive and cooperative interdependencies within the wider GAA figuration and shifted the power balance between clubs and county committees in the direction of the latter. The reason for this is that the functional dependency of clubs on their respective county committee for administrative, coordinating and regulating functions was greatly accentuated. A parallel process was occurring at inter-county level, as inter-county sports competitions increased in status the interdependencies between counties - in terms of rivalry and cooperation intensified-strengthening wefeelings based on county identification. The strength of such we-concepts (Elias, 1991) in conjunction with higher levels of functional interdependency between the subunits now exacerbated tensions and, at one level, moderated the pace of integration and centralizing tendencies. Disputes arose between clubs, between county committees, between provincial councils, between county committees and provincial councils, and indeed between central council and provincial councils, resulting in trials of strength between the various sub-units (see e.g. CLG Leinster Provincial Council Minutes 19251929). However, these tensions generated a parallel and contradictory tendency arising from these disputes and antipathies; the function of third-party adjudicator took on increasing importance. As such, both clubs and county committees became more dependent on provincial and central councils for their regulatory and administrative functions. Interrelated with this, the social existence of each unit, club, county committee, provincial council and central council became more interdependent as the functions they provided for one another increasingly interlocked and grew. This brings with it a compelling pressure for coordinating functions at a higher level of orientation, and upon which the other 'lower tier' units are more functionally dependent - a movement in the power ratio in the direction of the central coordinating unit takes place. That representatives of county committees simultaneously comprised these higher-tier units added to tensions surrounding how these units were structured and who should compose them.

The central council was, and was increasingly perceived to be, the primary social organ in which more and more decisions affecting, or perceived to be affecting, all units were being determined. One indication of this was the attempts by individual county committees for permanent representation on central council. From 1911, but particularly from the 1930s onwards, there were repeated attempts by county committees to amend the GAA constitution to allow for an individual representative from each county to become a member of central council (GAA, 1929; 1935; 1936; 1939, 
1940, 1946). The competitive tensions permeating the GAA figuration meant each county committee sought to protect or enhance what they perceived as their entitlements and interests, while simultaneously fearing the slightest advantage toward an opponent. Evidence of this can be gleamed from the motions, and resultant debates, at the GAA's national congress on the composition of the central council. For instance, one delegate at the 1939 congress supporting the proposal for individual county representation suggested, 'A county representative could keep his county in touch with the working of Council', while an opposing delegate countered: 'that if the motion was adopted a province with twelve counties could dominate the Central Council. It would be a lop-sided council' (GAA, 1939). However, in tandem with this, there occurred contradictory processes, as some GAA members, and in particular functionaries positioned at the highest level of orientation and coordination, sought a smaller 'executive committee' holding some functions, up to then the preserve of central council (GAA, 1942: 6-7).

More importantly, though, these and subsequent developments were not solely the result of the intra-organizational interdependencies and tensions outlined but were connected with figurational dynamics at different levels of integration, competition and cooperation. The competitive figuration the GAA comprised with organizations governing soccer, in particular, had tightened and widened-developments in communications and media meant the mediation of international and 'British' soccer in Ireland had expanded (see Boyle, 1992) - while the GAA's cooperative relations with the media also multiplied. Combined, this expansion in interdependencies generated pressures on those functions at the apex of the GAA charged with coordination and governance to develop quicker and more harmonized actions. For instance, in 1946 the general secretary of the GAA sought to enhance the function of central council by recommending the unit have the authority to arrange match fixtures over longer time periods as it was 'a matter that grows imperative because of the widespread demand for the broadcasting of our important games' (GAA, 1946: 15).

It was the structure and dynamic of these overlapping figurations that impelled the type of transformation that occurred in the organizational make-up of the GAA in 1946. While central council was finally expanded to give each individual county representation, at the same time, an 'executive committee' of twelve to 'deal with the routine matters' between meetings was created (GAA, 1946a: 57)-though there were still demands for individual county representation on this new committee (GAA, 1946b: 15-16).

That many individuals simultaneously comprised those different units underpins the problem of conceiving of these as separate interacting entities. Figurations help better capture the complex and contradictory nature of this process. By examining the strength of we-feelings towards one figuration over another by those comprising overlapping figurations, the constraints and compulsions this generates, in conjunction with shifts in the power-function relation, we can identify more clearly how and why specific changes occur. 


\section{Discussion and Conclusion}

This paper contributes to the literature on organizational change on several fronts and to organization theory more broadly. First, it illustrates the usefulness of the concept of figuration developed by Elias as a model for explaining the individual-organizationenvironment relationship within organization studies and in overcoming the inadequate and unhelpful concepts generated by structure-agency dualisms. Indeed, many of the laudable attempts at theorizing change continue to impose an impermeable barrier between individual-organization-environment. If we take figuration(s) as our starting point we can move beyond this and begin to identify the nature and degree of interdependence through which people are bound to one another in relatively short chains and longer and denser chains, and how organizations, identities, logics and rationalities are formed and altered through the interweaving of webs of functionally interdependent people. Moreover, the concept of figuration questions how we conceive of organizations - the type and the structure of organizational boundaries, and where such boundaries begin and end.

This brings us to the second contribution of this paper. While the theoretical approached associated with Bourdieu, and adopted by institutional theorists, provides a means to integrate habitus and wider social processes such as class relations, we contend that figurational theory adds a more nuanced approach. For although there are some similarities between the concepts of field and figuration, we argue that the dual, and related, concepts of figuration and we-I identity balances allow for a more adequate conceptual repertoire for observing how individuals are integrated at different levels into multiple, overlapping, and at times conflicting, social organizations.

A third contribution is the 'critical' challenge (Parker and Thomas, 2011) the paper proffers to existing organizational theory and, in particular, to the increasing ubiquity of a generally uncritical body of work on institutional theory. Even though some studies based on institutional theory identify competing and oppositional organizational logics and related power dynamics (Reay and Hinings, 2009; Spicer and Sewell, 2010), the conceptualization of power as multi-polar within a figurational approach provides a more comprehensive conceptual framework for understanding how the resistant activities and interests of weaker (intra-organizational) social actors can shape transformation; a weakness in other studies noted by Spicer and Sewell (2010). Thus, the desires of any one group or individual to steer the organization in a specific direction to match their objectives is difficult to achieve. Indeed, the focus on power relations, and the relational nature of power within figurational theory, both amplifies and gives greater credence to the dependency of more powerful actors on weaker ones.

Fourth, our study advances existing figurational studies of organizations and suggests potential avenues for organizational researchers in the future. While Elias has been brought into organization studies, several of these empirical studies (see Dopson 
and Waddington, 1996; Dopson, 2005) have tended to primarily focus on recurring or recent empirical cases. At the same time, there is a tendency to deploy Elias's concept of game models, while simultaneously giving less analysis and theoretical explication to multiple and fluid we-relations, the dynamic nature of the emotional charges that weidentifications generate at different levels of integration, and their long-term development. Such an analysis, we argue, should be integrated into figurational approaches to organization studies. Indeed, as our empirical case shows, the intensity of we-identities of social units at different levels of integration in concert with other social processes can facilitate, hinder or accelerate the type and extent of organizational change.

\section{Notes}

\footnotetext{
1 The GAA's organizational structures are based on an all-Ireland system of the four provinces and thirty two counties of Ireland; each county has a county committee that has considerable planning and operational responsibilities. The clubs in each county elect the county committee. Representatives of county committees also comprise a provincial council, for each of the four provinces of Ireland. They function at a higher level of planning and co-ordination than county committees.

2 The competition rules followed the 'British' upper-middle class sporting principles of amateurism.

3 Gaelic football developed from various versions of folk football played at that time in Ireland.

4 A game played with a long wooden stick and small ball, which has a long history in Ireland.

5 The county system was a British geographical system for administration in Ireland, which was at that time under the control of the British state.

6 This is a small sample from the hundreds of men who comprised administrative units of the GAA in the 1890s. The purpose is to illustrate how individuals comprise different yet overlapping figurations simultaneously.

7 CLG refers to Cumann Lúthchleas Gael the Irish-language version of the Gaelic Athletic Association and appears as the corporate author on some publications.
}

\section{References}

Barley, S. and Tolbert, P. (1997) 'Institutionalization and Structuration: Studying the Links between Action and Institution', Organization Studies 18(1): 93-117.

Battilana, J. (2006) 'Agency and Institutions: The Enabling Role of Individuals' Social Position', Organization 13(5), 653-76.

Blake, R. T. (1900) How the G.A.A. Was Grabbed. Publisher Unknown.

Bourdieu, P. (1990) The Logic of Practice. Cambridge: Polity.

Boyle, R. (1992) 'From our Gaelic Fields: Radio, Sport and Nation in Post-partition Ireland', Media, Culture and Society 14: 623-36.

CLG (1925-1929) Minutes of Leinster Provincial Council 1925-1929: Portlaoise: GAA.

Creed, W. Dejordy, R. and Lok, J. (2010) 'Being the Change: Resolving Institutional Contradiction through Identity Work,' Academy of Management Journal 53(6):1336-64.

De Búrca, M. (1984) Gaelic Games in Leinster. Leinster: Comhairle Laighean.

De Búrca, M. (1999) The GAA: A History. Dublin: Gill \& Macmillan.

Devine, L. (2002) 'The Twenties'. In Moran, T. (eds) Stair CLG Chonnacht 1902-2002, Carrick-on-Shannon: Carrick Print, pp. 23-36. 
Dopson, S. (2001) 'Applying an Eliasian Approach to Organizational Analysis', Organization 8(3): 515-35.

Dopson, S. (2005) 'The Diffusion of Medical Innovations: Can Figurational Sociology Contribute', Organization Studies 26(8): 1125-44.

Dopson, S. and Waddington, I. (1996) 'Managing Social Change: A Process-Sociological Approach to Understanding Organisational Change within the National Health Service', Sociology of Health \& Illness 18(4): 525-50.

Dunning, E. and Sheard, K. (1976) 'The Bifurcation of Rugby Union and Rugby League: A Case Study of Organizational Conflict and Change', International Review for the Sociology of Sport 11(2): 31-72.

Elias, N. (1978) What Is Sociology? New York: Columbia University Press.

Elias, N. (1984) The Court Society. New York: Pantheon Books.

Elias, N. (1987) Involvement and Detachment. Oxford: Basil Blackwell.

Elias, N. (1991) The Society of Individuals. Oxford: Basil Blackwell.

Elias, N. and Scotson, J. (1994). The Established and the Outsiders. London: Sage.

Elias, Norbert (2000) The Civilizing Process: Sociogenetic and Psychogenetic Investigations. Oxford: Blackwell Publishers.

Elias, N. and Dunning, E. (1966) 'Dynamics of Group Sports with Special Reference to Football', British Journal of Sociology 17(4): 388-402.

Elias, N. and Dunning, E. ( 2008) 'Quest for Excitement: Sport and Leisure in the Civilising Process', Revised Edition, Dublin: University College Dublin Press.

Fligstein, N. and McAdam, D. (2011) 'Toward a General Theory of Strategic Action Fields', Sociological Theory 29(1): 1-26.

GAA (1885) The Gaelic Athletic Association - Constitution and Rules 1885. Dublin: GAA.

GAA (1901) Minutes of Central Council. Dublin: GAA.

GAA (1925) Motions for Annual Congress Dublin: GAA

GAA (1929) Special Minutes of Annual Congress. Dublin: GAA.

GAA (1935) Minutes of Annual Congress. Dublin: GAA.

GAA (1936) Minutes of Annual Congress. Dublin: GAA.

GAA (1939) Minutes of the Annual Congress. Dublin: GAA.

GAA (1942) Minutes of Annual Congress. Dublin: GAA.

GAA (1946a) An Chomhdháil Bhliantúil. Dublin: GAA.

GAA (1946b) Minutes of Annual Congress. Dublin: GAA.

GAA (1953) Minutes of Annual Congress. Dublin: GAA.

GAA (1956) Official Guide. Dublin: GAA.

Gallogly, D. (1984) Cavan's Football Story. Cavan: Cavan County Committee of the Gaelic Athletic Association.

Garnham, N. (2004a) 'Accounting for the Early Success of the Gaelic Athletic Association', Irish Historical Studies xxxiv(133): 65-78.

Garnham, N. (2004b) Association Football and Society in Pre-Partition Ireland. Belfast: Ulster Historical Foundation.

Goodrick, E. and Reay, T. (2011) 'Constellations of Institutional Logics: Changes in the Professional Work of Pharmacists', Work and Occupations 38(3): 372-416. 
Haveman, H. and Rao, H. (1997) 'Structuring a Theory of Moral Sentiments: Institutional and Organizational Coevolution in the Early Thrift Industry', American Journal of Sociology 102(6): 1606-51.

Hodgson, G. (2007) 'Institutions and Individuals: Interaction and Evolution', Organization Studies 28(1), 95-116.

Holm, P. (1995) 'The Dynamics of Institutionalization: Transformation Processes in Norwegian Fisheries', Administrative Science Quarterly 40(3), 398-422.

Hunt, T. (2008) Sport and Society in Victorian Ireland. The Case of Westmeath. Cork: Cork University Press.

Hunt, T. (2009) 'The GAA: Social Structure and Associated Clubs'. In Cronin, M., Murphy, W. and Rouse, P. (eds) The Gaelic Athletic Association 1884--2009, Dublin: Irish Academic Press, pp.183-202.

Kee, R. (2000) The Green Flag: A History of Irish Nationalism. London: Penguin.

Kilminster, R. (1998) The Sociological Revolution: From the Enlightenment to the Global Age, London: Routledge.

Leca, B. and Naccache, P. (2006) 'A Critical Realist Approach to Institutional Entrepreneurship', Organization 13(5): 627-51.

Lee, J. (1989) Ireland 1912-1985. Cambridge: Cambridge University Press.

Mandle, W. F. (1987) The Gaelic Athletic Association and Irish Nationalist Politics, 18841924. Dublin: Gill and Macmillan.

McDevitt, P. F. (1997) 'Muscular Catholicism: Nationalism, Masculinity and Gaelic Team Sports, 1884-1916', Gender \& History 9(2): 262-84.

McGee, O. (2005) The IRB. The Irish Republican Brotherhood from the Land League to Sinn Fein. Dublin: Four Courts Press.

McMullan, M. (1995) 'Opposition, Social Closure, and Sport: The Gaelic Athletic Association in the 19th Century', Sociology of Sport Journal 12: 268-89.

McTernan, J. C. (eds) (1984) Sligo G.A.A. A Centenary History 1884-1984. Sligo: Coiste Chontae Shligigh.

Mennell, S. (1989) Norbert Elias. New York: Basil Blackwell.

Misangyi, V., Weaver, G. and Elms, H. (2008) 'Ending Corruption: the Interplay Among Institutional Logics, Resources, and Institutional Entrepreneurs', Academy of Management Review 33(3): 750-70.

Mulvey, J. (2002a) 'A New Dawn'. In Moran, T. (eds) Stair CLG Chonnacht 1902-2002, Carrick-on-Shannon, Co. Leitrim: Carrick Print, pp.11-22.

Mulvey, J. (2002b) 'Sowing the Seed'. In Moran, T. (eds) Stair CLG Chonnacht 1902-2002, Carrick-on-Shannon: Carrick Print, pp. 1-10.

Newton, T. (2001) 'Organization: The Relevance and Limitations of Elias', Organization 8(3): 467-95.

Newton, T. (2004) 'From Freemasons to the Employee: Organization, History and Subjectivity', Organization Studies 25(8): 136-87.

Nolan, W. (eds) (2005) The Gaelic Athletic Association in Dublin 1884-2000. Dublin: Geography Publications.

O'Sullivan, T. F. (1916) The Story of the G.A.A. Dublin: Publisher Unknown. 
Ó Riain, S. (1994) Maurice Davin (1842-1927). First President of the G.A.A. Dublin: Geography Publications.

Paulle, B., van Heerikhuizen, B. and Emirbgyer, M. (2011) 'Elias and Bourdieu'. In Susen, S. and Turner, B. (eds) The Legacy of Pierre Bourdieu: Critical Essays, London: Anthem press, pp.145-72.

Parker, M. and Thomas, R. (2011) 'What is a Critical Journal?', Organization 18(4): 41927.

Rao, H., Monin, P. and Durand, R. (2003) 'Institutional Change in Toque Ville: Nouvelle Cuisine as an Identity Movement in French Gastronomy', American Journal of Sociology 108(4): 795-843.

Reay, T. and Hinings, C. R. (2005) 'The Recompositition of an Organizational Field: Health Care in Alberta', Organization Studies 26(3): 351-84.

Reay, T. and Hinings, C. R. (2009) 'Managing the Rivalry of Competing Institutional Logics', Organization Studies 30(6): 629-52.

Reed, M. (1997) 'In Praise of Duality and Dualism: Rethinking Agency and Structure in Organizational Analysis', Organization Studies 18(1), 21-42.

Reed, M. (2005), 'Reflections on the 'Realist Turn' in Organization and Management Studies', Journal of Management Studies 42(8): 1621-44.

Scott, W. R. (2008) 'Approaching Adulthood: The Maturing of Institutional Theory', Theory and Society 37(5): 427-42.

Seo, M.-G., \& Creed, W. (2002) 'Institutional Contradictions, Praxis, and Institutional change: A Dialectical Perspective', Academy of Management Review, 27(2), 222-47.

Spicer, A. and Sewell, G. (2010) 'From National Service to Global Player: Transforming the Organizational Logic of a Public Broadcaster', Journal of Management Studies 47(6): 913-43.

Van Iterson, A., Mastenbroek, W., Newton, T. and Smith, D. (eds) (2002) The Civilized Organization. Norbert Elias and the Future of Organization Studies Amsterdam: John Benjamins Publishing Company.

Van Iterson, A., Mastenbroek, W. and Soeters, J. (2001) 'Civilizing and Informalizing: Organizations in an Eliasian Context', Organization 8(3): 497-514.

Vaughan, D. (2008) 'Bourdieu and Organizations: The Empirical Challenge' Theory and Society 37(1): 65-81.

Washington, M. (2004) 'Field Approaches to Institutional Change: The Evolution of the National Collegiate Athletic Association 1906-1995', Organization Studies 25(3): 393414.

Wright, A. (2009) 'Domination in Organizational Fields: It's Just Not Cricket', Organization 16(6): 855-85. 